LEANNE ROSE-MUNRO

\title{
EVALUATING LEARNING ENVIRONMENTS FOR THE INCLUSION OF STUDENTS WITH HEARING DIFFICULTIES
}

\section{CONTEXT}

This chapter outlines an interdisciplinary approach to research and evaluation that accounts for technological innovations, pedagogical shifts and new legislative requirements for inclusion. Utilizing a mixed method multiple case study involving three students with hearing difficulties in one New Generation Learning Environment, the research described in this chapter explores issues surrounding the inclusion of students with hearing difficulties in new generation learning environments.

At the time of writing, the study was in the final stages of data collection. This research explores the students' perceptions of inclusion, aiming to uncover instances of opportunity for equitable participation in speaking, listening and learning situations. Underpinning this research is Brinkerhoff's Success Case Methodology, and Radcliffe's Pedagogy / Space / Technology Learning Environment Evaluation Framework. Whilst data collection methods privilege student voice, other corroborating evidence such as quantitative acoustic measures to determine the buildings capacity to control noise was collected. Photographs for the purpose of photo elicitation were gathered in an effort to enhance validity and support a multi-lens approach to understanding the setting. Interviews with school principals, teachers and students, with follow-up focus group discussions, broadened insights into the daily occurrences in the space.

The study contributes to the development of universally inclusive learning environments by providing new approaches to evaluating learning environments for the inclusion of students with hearing difficulties.

\section{INTRODUCTION}

In mainstream school settings, a significant number of students have hearing difficulties. Recently it has become clear that even minimal hearing loss (16-25dB) can affect academic achievement (Spencer and Marschark, 2010). It is therefore important to evaluate how New Generation Learning Environments (NGLE) help or hinder equitable access to learning opportunities and inclusion by students with hearing difficulties.

Drawing on Radcliffe's (2009) Learning Environment Design and Evaluation Framework and Brinkerhoff's (2008) Success Case Methodology, this research empirically maps the intersection between pedagogy, technology and space to determine if learning potentials of students with hearing difficulties can be facilitated in NGLE. Radcliffe's (2009) design and evaluation framework 
demonstrates the interplay between pedagogy, space and technology whilst providing an approach with which to address a host of issues associated with learning spaces. This research endeavours to add to the body of evidence that builds teacher capacity when it comes to manipulating the learning environment to maximise the learning potentials and inclusion of students with hearing loss.

In recent times, technology has changed the way educational spaces are configured and used. Increasingly, they are being designed to support speaking, listening and communication where collaboration, group work, complex problem solving, digital information gathering and publishing occur. These innovations and recent changes in legislation have highlighted the need for equitable access to learning environments for students with learning differences (disabilities). In designing NGLE there must be confidence that they are fit for purpose, account for diversity and ensure that speaking, listening and communication is accessible. These new spaces must support quality teaching and learning while also catering for the needs of all occupants.

NGLE design intends to support pedagogies based upon the Vygoskian premise that learning is constructed in a social context. These spaces reflect a constructivist approach, one that argues that humans generate knowledge and meaning from interactions between their experiences and their ideas (Creswell \& Plano Clark, 2011).

In mainstream school settings there is a diverse range of students with a variety of learning potentials and abilities. Based on his research of the developmental potentials in children, Vygotsky stressed the intactness rather than the deficits of the child. He commented:

A handicapped child represents a qualitatively different, unique type of development ... . If a blind or deaf child achieves the same level of development as the normal child, then the child with a defect achieves this in another way, by another course, by another means; and, for the pedagogue, it is particularly important to know the uniqueness along the course he must lead the child. This uniqueness transforms the minus of the handicap into the plus of compensation (Vygotsky,in Sacks, 1995),

The term 'mainstream' implies that children will need to adapt to fit in to the majority culture, and inclusion signifies that the program will make adaption's to fit the needs of all students in the classroom (Stinson \& Foster 2000). In determining elements in NGLE that contribute to inclusion, it is important to consider the quality of the child's experiences whilst accounting for opportunities that help or hinder participation. A medical model of inclusion predetermines that many young people will lack achievement in education and assigns that lack of achievement to the child's own deficit rather than the educational environment's failure to support them to learn (Abbott 2007). In contrast, this research project sits within a transformative theoretical framework that aims to advance the needs of underrepresented or marginalized populations (Creswell \& Plano Clark, 2011), and as such, endeavours to uncover the affordances of the learning environment that enhance inclusion. 
Istance (2011) contends that learning in the $21^{\text {st }}$ Century is not an entirely private matter associated first and foremost with the individual, but rather an accomplishment with and through others within a learning environment. This perspective is at odds with the traditional bureaucratic nature of educational institutions and formalized schooling structures that were based upon individualistic thinking. Instance (2011) further asserts that in seeking 'what works' in education, collective holistic solutions that take into account what happens at the macro, meso and micro levels are required. In evaluating inclusion in the learning environment it is acknowledged that policy (macro level) and governance (meso level), impact individuals differently within the learning environment at the micro level.

In formulating the methodology for this research, consideration was given to the kind of evidence deemed appropriate to support the inferences made about the level of opportunity and inclusion available to students with hearing difficulties in NGLE. Given the absence of evidenced-based research on inclusion of 'mainstreamed' students with hearing difficulties in NGLE, a multifaceted, multilens approach to data collection was taken to ensure reliability, validity and to mitigate researcher bias when evaluating student perceptions about the environment (Blackmore, Bateman, Loughlin, O'Mara, \& Aranda, 2011; Spencer \& Marschark, 2010).

Front of mind in considering the student's perceived level of inclusion is the quality of their experiences in the learning environment and their interpretation of such. Gibson (1977) describes an affordance as a quality of an object or an environment that allows an individual to perform an action (Gibson, 1977; Wright \& Parchoma, 2011). Affordances are also properties of the system, as perceived by the user, that allow certain actions to be performed and which encourage specific types of behaviour (Cox et al., 2003). Affordances speak directly to the quality of an experience as a result of an action, and in doing so go beyond the current rhetoric of inclusive education policies that speak to the notion of reasonable adjustments ("Disability Discrimination Act 1992," 1992; "Disability Standards for Education 2005," 2005).

Research questions asked in this study included:

- What is the lived experience of students with hearing difficulties in new generation learning environments?

- How are teachers planning the use of the environment to promote inclusion?

- What level of noise is present in the environment?

- How and in what ways is communication facilitated?

- What elements within the open-plan learning environment facilitate opportunity for participation in speaking and listening?

- The primary aims of the project were twofold: to investigate the affordances of the environment that enhanced inclusion for students with auditory disorders and to investigate factors that enabled hearing accessibility in open-plan new generation learning environments.

The subsidiary aims were to: 
- Investigate the environment's technology and acoustical affordances and properties to determined their influences on inclusion and subsequently what affordances should be adopted as best practice initiatives, and to

- Investigate the teachers' and students' preferential use of places to communicate within the learning space to determine how new generation learning environments could be best utilized for optimal access to speaking and listening activities.

\section{BACKGROUND: 21ST CENTURY STUDENTS WITH HEARING DIFFICULTIES}

Current research indicates that a significant number of students experience hearing difficulties. Australian Hearing, a statutory authority constituted under the Australian Hearing Services Act 1991, provided services to 68,296 eligible children and young Australians with hearing loss during 2012-2013 (Australian Hearing Annual Report 2012 / 2013, 2013). An overwhelming majority of these students attended mainstream schools in their local communities (Byrnes, 2011; Vosganoff, Paatsch, \& Toe, 2011).

Recently, Australian Hearing has introduced a new service that now diagnoses a hearing-related difficulty known as a Central Auditory Processing Disorder (CAPD), a subset of Auditory Processing Disorder (Bellis, 2002). Those diagnosed with CAPD find concentrating on speech and other cognitive tasks in the presence of background noise difficult, even though they do not have a hearing loss. In particular cases, students may have poor attention-switching abilities that are exasperated by noisy environments. CAPD impacts at least $10 \%$ of the indigenous population and $64 \%$ of adults over 55 years of age. (The Hearing Cooperative Research Centre, 2014; Nelson \& Soli, 2000; Wallach, 2011 ).

Collectively, $15 \%$ of the Australian population may have an Auditory Processing Disorder (APD) described as a listening in noise difficulty with or without the presence of a diagnosed hearing loss (Bellis, 2002; The Hearing Cooperative Research Centre, 2014; Sharma \& Heine, 2011; Sharma, Purdy, \& Kelly, 2009). Additional studies have linked young children who commonly experience middle ear infections with hearing loss and APD (Flexer, Smaldino, \& Crandell, 2005; Howard, Munro, \& Plack, 2010). Research also indicates that younger students experience greater levels of hearing difficulties as the auditory network pathway responsible for decoding auditory verbal information is developing and continues to develop up to the age of 15 years (Smaldino \& Flexer, 2012).

Further research indicates that students for whom English is an additional language, and those with speech and language difficulties, learning difficulties, cognitive disorders, attention disorders and behavioural problems also have difficulties listening and interpreting speech in noise (Massie \& Dillon, 2006; Rowe, Rowe, \& Pollard, 2004; Sharma et al., 2009; Shield, Greenland, \& Dockrell, 2010; Smaldino \& Flexer, 2012; Snow \& Powell, 2008). It is also widely reported that noisy environments adversely affect students with sensory disorders such as autism and vision loss by impacting cognition, heightening anxiety and 
diminishing access to clear speech (Anderson, 2001; Clark \& Sorqvist, 2012; Guardino \& Antia, 2012; Katte, Bergstroem, \& Lachmann, 2013; Smaldino \& Flexer, 2012).

\section{FIGURE POLICY AND GOVERNANCE AND THE IMPACTS UPON INDIVIDUALS}

Transparency and Accountability and Meeting Student Need are key areas of reforms that can play a role in addressing the quality of hearing accessibility in the built learning environment (Hooge, Burns, \& Wilkoszewski, 2012). The connection arises as educational institutions must account for the quality of services provided, in terms of quality of education (effectiveness), value for money (efficiency), equity and access ("Australian Education Act 2012," 2012). Building compliance and legislated regulations can be used highly effectively to Meet Student Need, for example, provision of appropriate hearing access solutions and listening environments for hearing impaired students and students with additional sensory needs such as autism and vision loss (Guardino \& Antia, 2012; Hooge et al., 2012; Hyde \& Palmer, 2010). Figure 1 gives an overview of current legislative initiatives underpinned by human rights movements that aim to enhance accessibility to quality experiences for people with differences (disability) in public meeting spaces in Australia. This encapsulates learning environments that are classified in the Building Code of Australia as a Class $9 \mathrm{~b}$ building, public meeting space.

Innovations in acoustic design, building materials, and legislative changes that broaden the scope of hearing access continue to develop. However, research on a range of benchmark standards aimed at reducing noise and increasing hearing accessibility in open-plan learning environments is limited.

Emerging methodologies must reflect the researcher's awareness of their own, and competing paradigms, whilst adhering to the standards of their own methodological perspectives. The evidence must be reliable, valid and trustworthy; account for theoretical perspectives; aim to develop generalizations based on findings, and add to the understanding of issues in education (Bradley, Royal, Cunningham, Weber, \& Eli, 2008). 

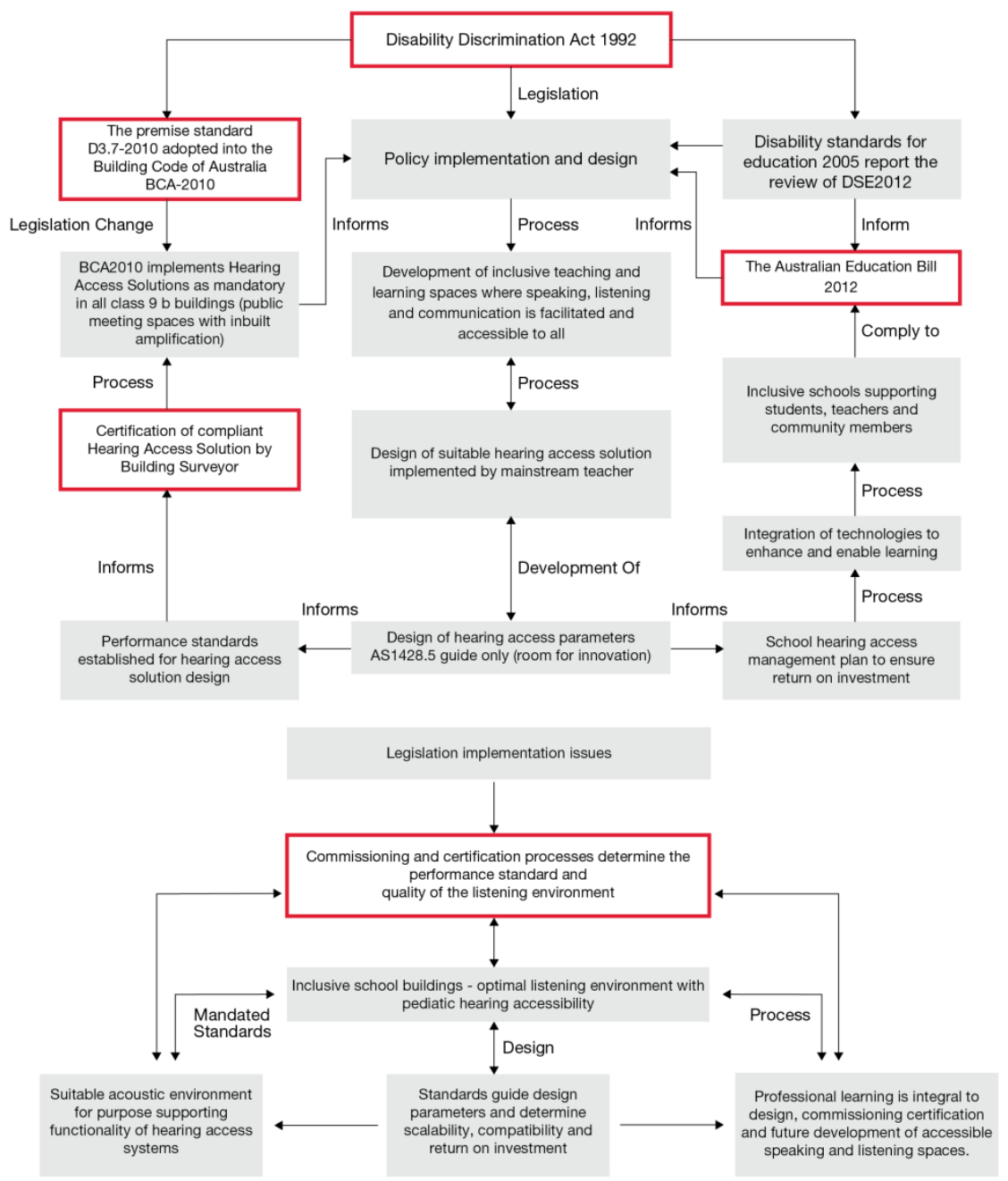

Figure 1. Overview of current Australian legislative initiatives underpinned by human rights movements

\section{EMERGING METHODOLOGICAL APPROACHES}

Learning spaces are auditory verbal environments where the primary information exchange occurs through speaking and listening activities (Munro, 2011). This poses a substantial barrier to the estimated $25-30 \%$ of students in every class that have a hearing difficulty, particularity when it comes to accessing learning opportunities involving speaking and listening. Currently little is known about students with hearing difficulties in open-plan learning spaces and how they 
engage with auditory and visual cuing opportunities using a range integrated technologies in the context of differentiated and personalized learning.

Presently there are no known optimal acoustic design parameters and measures for open-plan NGLE (Shield, Greenland, Dockrell, 2010, Robinson, Rose-Munro, 2014). Yet a broad body of 'deaf education' research in recent times highlights the urgent need to optimize learning environment acoustics, particularly in mainstream settings. This is in order to address the quality of, and accessibility to, communication experiences, social emotional inclusion and to enable equitable development of learning potentials. In addition, much of the previous 'deaf education' research accounts for traditional cellular classroom settings and pedagogies (Vosganoff, Paatsch,Toe, 2011, Smaldino, Flexer, 2012, Nelson, Soli, 2000).

In evaluating the level of inclusion in NGLE as perceived by students with hearing difficulties, account must be given to fast-paced changes and innovations occurring in the environment and how these changes affect students with hearing impairment. Kay (2010) asserts it is unfair and unproductive to expect students to meet new and higher expectations in 21 st century learning spaces if the supporting infrastructure is not there (Bellanca \& Brandt, 2010). However, little is known about technological, pedagogical and acoustical affordances in NGLE and how these elements play a role in creating new experiences for students with hearing difficulties (Brown \& Eisenhardt, 1997; Glaser \& Strauss, 1967; Spencer \& Marschark, 2010).

Brinkerhoff (2005) developed the Success Case Methodology, a method for evaluating the impacts of change and learning on institutions. This methodology was selected for this research project because it accounts for the performance management system and acknowledges the role that learning plays in it to achieve results. For example, in evaluating the effectiveness of learning environments, account is given to the teachers' understandings of the built environment and how they engage with affordances of the space. In doing so, a teacher's capacity to manipulate space is evaluated and considered alongside a student's perception of inclusion. These grounded theory-building approaches are more likely to generate novel and accurate insights into rarely explored phenomenon under study rather than rely on past research, particularly in times of fast-paced change (Glaser \& Strauss, 1967; Hart, 1990).

\section{METHODOLOGY AND METHODS}

Figure 2 is a visual representation of the Pedagogy-Space-Technology Framework (Radcliffe, 2009) in conjunction with Success Case Methodology (Brinkerhoff 2008). The methodological approach aims to explore issues of inclusion for students with hearing difficulties whilst accounting for the complexity of variables that may impact the performance standard of the learning environment. The student's experience is situated at the centre of the learning environment evaluation process. 


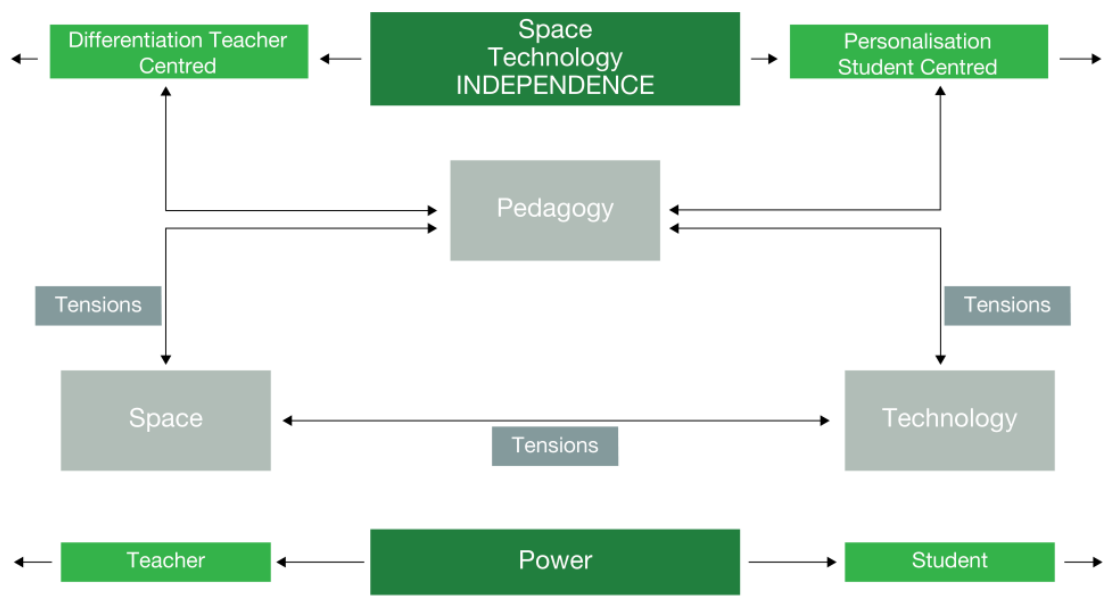

Figure 2. Pedagogy-Space-Technology Framework (Radcliffe, 2009) \& Success Case Methodology (Brinkerhoff 2008) exploring issues of inclusion in NGLE

The study described in this chapter utilized a mixed method multiple case study design involving three students with hearing difficulties in one NGLE in which the students form the cases and the school is the site.

The aim of the emergent methodological approach was to capture convergent and divergent thinking regarding the intersection of the elements of pedagogy, space and technology in NGLE, and the subsequent impact upon inclusion of students with hearing difficulties. Radcliffe's (2009) Pedagogy, Space, Technology Learning Environment Evaluation Framework was utilized as grounding for this research because it offered a simple framework that identified patterns in what institutions are trying to achieve, the ways in which they do this, and how they evaluate success. The questions asked within the framework can be tailored to meet particular ways of doing work, and the process is one which is "inherently selfdocumenting and aids the elicitation of lessons learned for future projects" (Radcliffe pp.14, 2009).

Brinkerhoff's (2008) Success Case Methodology explores 'what works' in times of fast-paced change whilst accounting for the 'value-add' of learning. The intended outcome of the approach is to identify affordances that enable inclusion of students with hearing difficulties in NGLE.

The objectives of the selected methods were to:

- Visually capture every day occurrences within the learning environment

- Record the acoustical properties of the learning environment

- Record accessibility to technology within the learning environment

- Document teachers and students perceptions of inclusion within the learning environment. 
Table 1 summarizes the qualitative data collection methodology and aims. The evaluation framework questions were explored through semi-structured interviews with the case study students, their respective teachers, and principals. All interviews were transcribed, coded and thematically analysed. The qualitative data collection sought to understand how the elements of pedagogy, space, and technology interrelate in the learning environment to facilitate communication.

Photographs of the learning environment were taken at various phases of the data collection process. This iterative approach allowed for the capturing of occurrences as they emerged. This approach to photo elicitation also enabled the participants and researcher to interrogate their own understandings of the phenomena under investigation (Moss, 2008). For example, students were asked to identify their favourite positions in the learning environment and photographs of these spaces were later used to elicit responses from other students and teachers. Teachers were intermittently photographed explicitly teaching in various positions, and later, their decision-making regarding positioning in the space was interrogated. Furthermore, photographs of furniture placement and positioning of visual and auditory technology tools were used to elicit responses from participants.

The images were compared with written notes, recorded interviews and acoustic data. A noise logger, an acoustical measurement tool, logged the average equivalent background noise measured in decibels over time within a set position in the NGLE. This measure gave an indication of the typical background noise levels that students and teachers commonly experienced within this space over time. In addition, reverberation times were measured at strategic locations throughout the built environment. This was utilized as a simple indication of how the building was performing in terms of absorbing sound reflections or noise echoes. 
Table 1.Qualitative Data Collection Methods Aims and Objectives

\begin{tabular}{|c|c|c|c|c|}
\hline $\begin{array}{l}\text { Data } \\
\text { Collection } \\
\text { Models }\end{array}$ & $\begin{array}{c}\text { Formal \& } \\
\text { Informal } \\
\text { Observations }\end{array}$ & $\begin{array}{c}\text { Photo } \\
\text { Elicitation }\end{array}$ & $\begin{array}{c}\text { Semi-structured } \\
\text { Interviews }\end{array}$ & Focus Groups \\
\hline $\begin{array}{l}\text { Data } \\
\text { collection } \\
\text { aims and } \\
\text { objectives: } \\
\text { Record the } \\
\text { convergence } \\
\text { of the } \\
\text { elements of } \\
\text { pedagogy, } \\
\text { space, } \\
\text { technology in } \\
\text { the NGLE and } \\
\text { the } \\
\text { subsequent } \\
\text { impact upon } \\
\text { inclusion of } \\
\text { students with } \\
\text { hearing loss. }\end{array}$ & $\begin{array}{l}\text { Record } \\
\text { pedagogical } \\
\text { enactment } \\
\text { through } \\
\text { mapping } \\
\text { actions. } \\
\text { Record } \\
\text { planning } \\
\text { processes and } \\
\text { placement of } \\
\text { activities and } \\
\text { people. } \\
\text { Observe and } \\
\text { record actions } \\
\text { and reactions } \\
\text { to events } \\
\text { within the } \\
\text { space. } \\
\text { Monitor } \\
\text { accessibility } \\
\text { to, and use of } \\
\text { technology. } \\
\text { Monitor } \\
\text { furniture } \\
\text { placement. }\end{array}$ & $\begin{array}{l}\text { Take } \\
\text { photographs for } \\
\text { the purpose of } \\
\text { eliciting a } \\
\text { response } \\
\text { regarding } \\
\text { placement } \\
\text { within the } \\
\text { space. } \\
\text { Preference of } \\
\text { positions. } \\
\text { Understand } \\
\text { intended } \\
\text { outcomes of } \\
\text { furniture } \\
\text { arrangements. } \\
\text { Clarify } \\
\text { perceptions } \\
\text { regarding } \\
\text { accessibility to } \\
\text { speaking and } \\
\text { listening in } \\
\text { particular } \\
\text { spaces and } \\
\text { places. } \\
\text { Collect } \\
\text { corroborating } \\
\text { evidence of } \\
\text { perception of } \\
\text { inclusion. } \\
\text { Capture visual } \\
\text { documentation } \\
\text { the lived } \\
\text { experience in a } \\
\text { moment in } \\
\text { time. }\end{array}$ & $\begin{array}{l}\text { Seek } \\
\text { explanations } \\
\text { regarding the } \\
\text { planning process } \\
\text { and placement of } \\
\text { activities, } \\
\text { furniture and } \\
\text { people. } \\
\text { Seek an } \\
\text { understanding of } \\
\text { how students } \\
\text { access speaking, } \\
\text { listening and } \\
\text { communication. } \\
\text { Seek an } \\
\text { understanding of } \\
\text { beliefs and } \\
\text { perceptions } \\
\text { regarding } \\
\text { technology use. } \\
\text { Spatial } \\
\text { awareness and } \\
\text { perception of } \\
\text { inclusion. }\end{array}$ & $\begin{array}{l}\text { Deepen and } \\
\text { broaden } \\
\text { understandings } \\
\text { of } \\
\text { teacher/student } \\
\text { interpretation of } \\
\text { accessibility to } \\
\text { visual and } \\
\text { auditory cues. } \\
\text { Clarify } \\
\text { perception of } \\
\text { accessibility to } \\
\text { speaking, } \\
\text { listening and } \\
\text { communication. } \\
\text { Clarify } \\
\text { accessibility to } \\
\text { technology. } \\
\text { Clarify noise } \\
\text { control } \\
\text { strategies; } \\
\text { learning } \\
\text { strategies. } \\
\text { Clarify } \\
\text { perceptions of } \\
\text { inclusion. }\end{array}$ \\
\hline
\end{tabular}


Quantitative data were gathered and analysed in an effort to uncover evidence that corroborated or clarified what helped or hindered communicative opportunities for students with hearing difficulties in NGLE.

Table 2 summarizes the aims and objectives of the quantitative data collection methods.

Table 2. Quantitative Data Collection Aims and Objectives

\begin{tabular}{|c|c|c|}
\hline Data Collection Methods & Aims & Objectives \\
\hline $\begin{array}{l}\text { Building Acoustical } \\
\text { Measurements }\end{array}$ & $\begin{array}{l}\text { Quantitative data regarding } \\
\text { noise levels in the built } \\
\text { learning environment and } \\
\text { the building's capacity to } \\
\text { control noise } \\
\text { Measure: } \\
\text { Reverberation times } \\
\text { Noise logger } \\
\text { Speech perception test } \\
\text { Noise pressure levels }\end{array}$ & $\begin{array}{l}\text { Accessibility to speech } \\
\text { intelligibility } \\
\text { Noise levels and impacts of } \\
\text { cognition; opportunity to } \\
\text { engage. }\end{array}$ \\
\hline $\begin{array}{l}\text { Architectural Documents \& } \\
\text { Drawings }\end{array}$ & $\begin{array}{l}\text { Building specifications } \\
\text { Building documentation } \\
\text { Design brief }\end{array}$ & $\begin{array}{l}\text { Policy and procedure } \\
\text { guidelines regarding the } \\
\text { built learning space's } \\
\text { capacity to support speaking } \\
\text { and listening } \\
\text { Legislated building } \\
\text { performance standards }\end{array}$ \\
\hline Technology Audit & $\begin{array}{l}\text { Identification of the presence } \\
\text { and placement of visual and } \\
\text { auditory assistive } \\
\text { technologies }\end{array}$ & Accessibility to technology \\
\hline
\end{tabular}

The emergent methodological approach was iterative, allowing for adjustments in response to data collection and the potential for uncovering rich and in-depth findings about complex phenomena that was not clearly understood (Glaser \& Strauss, 1967; Stake, 1995).

\section{CONCLUSION}

This multi-lens approach valued collaboration sits within the philosophical framework of $21^{\text {st }}$ Century learning environments. The ontological and epistemological stance of this research also sits within a transformative framework that is concerned with emancipatory education that wishes to further the cause of 
under-represented and marginalized groups (Biesta \& Safstrom, 2011; Freire, 1970; Hart, 1990).

Sampling is purposeful in Success Case Methodology because the focus is on systems and leveraging resources into continuously improved performance, and outputs included the sharing of knowledge gained. Success Case Methodology, although perhaps not in its purest form, seemed particularly well suited to evaluating the complexities of the performance of New Generation Learning Environments. This was because the users of the environment, i.e. the students and teachers, reported successes and difficulties at the micro level, creating feedback that strategically outlined evidence-based opportunities for adjustments at the meso (Governance) and macro (Policy) levels. In the formulation of this methodological approach, academic achievement outcomes were not considered as corroborating evidence of the students' perception of inclusion in the NGLE. This was because learning outcomes were not under investigation. The performance standards of the learning spaces that enabled opportunities for participation in learning experiences were the central focus of this learning environments evaluation research.

Broad approaches such as those described above are supported by Kalikoff who put the case for a mosaic approach that involved the implementation of a series of textured and complementary evaluation strategies that aimed to provide reliable and detailed information about what was being accomplished in the context of the environment under investigation (Kalikoff, 2001).

Today, more than ever, school management systems and infrastructure are increasingly required to improve the capacity of the performance drivers and professionally develop staff in an effort to keep up with successful innovative approaches. Success Case Methodology recognizes that learning is a necessary but insufficient condition to produce substantive outcomes; performance is the driver of impact (Brinkerhoff, 2005). In the context of this study consideration was given to teacher professional learning regarding new pedagogical approaches, technology innovations and new learning spaces. Identifying how these interrelated elements perform in NGLE, and the subsequent impacts upon inclusion of students with hearing difficulties was found to be essential.

\section{REFERENCE LIST}

Anderson, K. (2001). Kids in Noisy Classrooms: What does the Research Really Say? [Journal]. Journal of Educational Audiology 9, 21-33.

Australian Education Act 2012 (2012).

Australian Hearing Annual Report 2012 / 2013. (2013). Canberra: The Office of Hearing Service Commonwealth Government of Australia Retrieved from http://www.hearing.com.au/wpcontent/uploads/2013/09/Australian-Hearing-Annual-Report-2012_13.pdf.

Bellanca, J., \& Brandt, R. (2010). 21st Century Skills; Rethinking how students learn. Bloomington,IN: Solution Tree Press.

Bellis, T. (2002). When the brain can't hear:Unraveling the mystery of auditory processing disorder. New York: Poket Books.

Biesta, G., \& Safstrom, C., A. (2011). A Manifesto For Education. Policy Futures in education, 9(5), 540-547. 
Blackmore, J., Bateman, D., Loughlin, J., O'Mara, J., \& Aranda, G. (2011). Research into the connection between the built learning spaces and student outcomes (D. o. E. a. E. C. a. Development, Trans.). Melbourne: Department of Education and Early Childhood Development.

Bradley, K., Royal, K., Cunningham, J., Weber, J., \& Eli, J. (2008). Mid-Western Educational Researcher 21(1).

Brinkerhoff, R. (2005). The Success Case Method: A Strategic Evaluation Approach to Increasing the Value and Effect of Training. Advances in Developing Human Resources, 7, 86-101. doi: $10.1177 / 1523422304272172$

Brown, S., \& Eisenhardt, K. (1997). The art of continuous change: Linking complexity theory and timepace evolution in relentlessly shifting organizations. Adminstrative Science Quarterly, 42, 1-34.

Byrnes, L. (2011). Listening to the voices of students with disability: What do adolscents with hearing loss think about different educational settings? Deafness and Education International, 13(2).

Clark, C., \& Sorqvist, P. (2012). A 3 year update on the influence of noise on performance and behavior. Noise \& Health, 14(16), 292-296.

Cox, M., Webb, M., Abbott, C., Blakeley, B., Beauchamp, T., \& Rhodes, V. (2003). ICT and pedagogy: A review of the research literature. In B. E. C. a. T. Agency (Ed.), FutureLab Series (Vol. 18). London.

Creswell, J., \& Plano Clark, V. (2011). Designing and conducting mixed methods reserach. California: Sage.

Disability Discrimination Act 1992 (1992).

Disability Standards for Education 2005 (2005).

Flexer, C., Smaldino, J., \& Crandell, C. (2005). Sound Field Amplification Applications to Speech Perception and Classroom Acoustics (Vol. Second Edition). Canada: Thomson Demar Learning.

Freire, P. (1970). Pedagogy of the Oppressed (Vol. Penguin Books). England.

Gibson, J. (1977). The Theory of Affordances. In R. Shaw \& J. Bransford (Eds.), Percieving, acting and knowing : Toward an ecological psychology. Oxford: Oxford University Press.

Glaser, B., \& Strauss, A. (1967). The Discovery of Grounded Theory: Strategies for Qualitative Research. London: Weidenfeld and Nicholson.

Guardino, C., \& Antia, S. (2012). Modifying the classroom environment to increase engagement and decrease disruption with students who are deaf or hard of hearing. Journal of Deaf Studies and Deaf Education, 17(4), 518-533.

Hart, M. (1990). Critical theory and beyond: Further perspectives on emancipatory education Adult Education Quartely, 40(3), 125-138.

The Hearing Cooperative Research Centre. (2014). The Hearing Cooperative Research Centre Retrieved 10/5/2014, 2014, from http://www.hearingcrc.org/home

Hooge, E., Burns, T., \& Wilkoszewski, H. (2012). Looking beyond the numbers: Stakeholders and Mutiple School Acountabilities. In OECD (Ed.), OECD Education Working Papers (Vol. 85): OECD.

Howard, C., Munro, J., \& Plack, C. (2010). Listening effort at signal to noise ratios that are typical of the school classroom. International Journal of Audiology 49, 928-932.

Hyde, M., \& Palmer, C. (2010). Understanding sensory impairment Diversity and inclusion in Australian schools.

Kalikoff, B. (2001). From coersion to collaboration:A mosaic approach to writing center. . Writing Lab Newsletter, 26(1), 5-7.

Katte, M., Bergstroem, K., \& Lachmann, T. (2013). Does noise affect learning? A short review on noise effects on cognitive performance in children. Frontiers in Psychology, 4(578).

Massie, R., \& Dillon, H. (2006). The impact of sound-field amplification in mainstream cross-cultural classrooms: Part 1 Educational outcomes. Australina Journal of Education 50(1), 62-77.

Moss, J. (2008). Researching Education Visually-Digitall-Spatially. The Netherlands: Sense Publishers.

Munro, J. (2011). Teaching Oral Language Building a Firm Foundation Using ICPALER in the Early Primary Years. Camberwell: ACER Press. 
Nelson, P., \& Soli, S. (2000). Acoustical Barriers to Learning: Children at Risk in Every Classroom. Language Speech and Hearing Services in Schools, 31(4), 356- 361.

Rowe, K. J., Rowe, K. S., \& Pollard, J. (2004). Literacy behaviour and auditory processing: Building fences at the top of the cliff in preference to fences at the bottom. Paper presented at the 2004Supporting student wellbeing: What does the reserach tell us about social and emotional development of young people?, Melbourne.

Sharma, M., \& Heine, C. (2011). Auditory Processing Disorders. Paper presented at the Auditory Processing Disorders: Contemporary Theory and Practice, Melbourne.

Sharma, M., Purdy, S., \& Kelly, A. (2009). Comorbidity of auditory processing, language and reading disorders. Journal of Speech and Hearing Research, 52, 706-722.

Shield, B., Greenland, E., \& Dockrell, J. (2010). Noise in open plan classrooms in primary schools: A review. Noise \& Health, 12(49), 225-234.

Smaldino, J., \& Flexer, C. (2012). Handbook of Acoustic Accessibility: Best practices for listening, learning and literacy in the classroom.

Snow, P., C,., \& Powell, B., C. (2008). Oral Language Competence, social skills and high risk boys: what are juvenile offenders trying to tell us? . Children and Society, 22, 16-28.

Spencer, P., \& Marschark, M. (2010). Evidence-Based Practice in Educating Deaf and Hard-of Hearing Students. Professional Perspectives on Deafness: Evidence and Applications. New York: Oxford University Press

Stake, R. (1995). The Art of Case Study Reserach. London: Sage.

Universal Design Principles. (2008), 2013, from http://www.design.ncsu.edu/cud/about_ud/ about_ud.htm

Vosganoff, D., Paatsch, L., \& Toe, D. (2011). The Mathmatical and Science Skills of Students who are Deaf or Hard of Hearing Educated in Inclusive Settings. Deafness and Education International, 13(2), 70-88.

Wallach, G. (2011 ). Peeling the onion of auditory processing disorder: A laguage / curricular-based perspective. Language Speech and Hearing Services in Schools, 42, 273-285.

Wright, S., \& Parchoma, G. (2011). Technologies for Learning? An actor-network theory critique of 'affordances' in reaserch on mobile learning Reserach in Learning Technology, 19(3), 247-258.

\section{Leanne Rose-Munro}

Melbourne Graduate School of Education,

The University of Melbourne 